\title{
地形改変の進んた丘陵地における強震動予測のための表層地盤モデルの構築 一名古屋大学東山キャンパスを例としてー \\ MODELING OF THE SURFACE LAYERS AT ARTIFICIAL TRANSFORMED HILL SITE FOR STRONG GROUND MOTION ESTIMATION \\ - On the Higashiyama campus of Nagoya university -
}

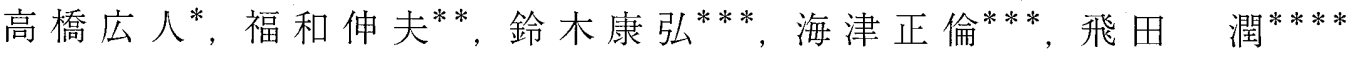 \\ Hirohito TAKAHASHI, Nobuo FUKUWA, Yasuhiro SUZUKI, \\ Masatomo UMITSU and Jun TOBITA
}

\begin{abstract}
A new method to estimate an accurate surface layer model is proposed for hilly area where the data on artificial transformation on ground is not sufficient. This method considers the distribution of surface layers and artificial transformation based on the topographical and geographical features on pre-transformed ground, which are newly evaluated by the aerial photographs on 1930's. Initial model for the 3-D surface layer structure is estimated based on the evaluated high-resolution map of landfill distribution, change of geomorphological land classification, and existing drilling data. Then the Vs profile for each site is revised by the dispersion curves evaluated by the array observation of microtremor. The accuracy of the method is confirmed at the Nagoya University campus by use of the observed seismic records. The presented method is effective for hilly areas where the heavy land transformation has been performed.
\end{abstract}

Keywords : hill ground, geomorphological land classification, cut and fill, aerial photograph, microtremor array observation, seismic records

丘陵地盤，微地形分類，切土盛土，空中写真，微動アレ一観測，地震観測記録

1. はじめに

近年，住宅の耐震化や地域の防災力向上を目指し，ハザードマッ プを公開する例が増加しつつある ${ }^{1)}$ 。住民に身近なスケールで地震 危険度を伝えるためには，予測震度の表示単位（メッシュサイズ） を小さくしたり，過去の地形改変との関連を示すことが効果的であ る。しかし，メッシュサイズが小さくなるほど，表層地盤モデルへ の感度は高くなる。最大加速度や震度はごく表層の地般のモデル化 によって増幅特性が大きく左右され，適切かつ明解な表層地盤のモ デル化方法が望まれている。

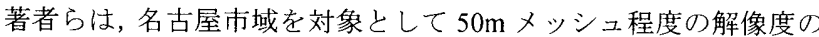
表層地盤のモデル化及び微動を用いた検証方法を提案している ${ }^{2)}$ 提案した手法における課題として, メッシュデータの限界, ボーリ ング資料の面的な疎密による地盤モデルの精度や切土・盛土分布の 高解像度化が挙げられる。

ボーリング資料を面的に補間するためには，地形分類図により， 地形分類ごとの空間的広がりと層厚を推定することが有効である。 地形分類を把握する方法として，国土地理院による土地条件図（縮 尺 1/25000）により調べることが可能である。しかし土地条件図に おいては, 地形改変が行われた地域は人工改変地と一括分類され,
そこが切土か盛土かいずれによる地形改変であるかが不明である。

一方, 切土・盛土分布は, 地形改変前後の地形図の標高データを 用いて 3 次元の地形面を作成することにより，広域的な評価が可能 であり，高精度化を図る上では，大縮尺の地形図の使用が有効であ る。しかし大都市圈では宅地造成による地形改変が古くから行われ ていることが多く, 地形改変前の大縮尺の地形図が得られない場合 もある。

本研究の対象とする名古屋大学東山キャンパスは，名古屋市東部 の丘陵地域に位置し，第二次世界大戦前から，校舎建設に伴う地形 改変が繰り返されてきた。図 1 に示すボーリング資料の分布から分 かるように，校舎建設時に実施された地盤調査の資料が豊富に蓄積 されており ${ }^{3)}$ ，ボーリング資料は 261 本に及ぶ。ただし，その分布 には疎密がある。

一方，地形分類図や地形図の元となる資料に空中写真がある。空 中写真は，一般には 1950 年代後半以降について入手可能であるが, 都市域においては, 旧日本陸軍により撮影された 1930 年代の空中写 真や米軍撮影による 1940 年代の空中写真がありここれらに基づけば 地形改変前の詳細な地形区分を推定できる き。さらに，地盤の震動 特性を検討するためには地震観測が有効である。名古屋大学東山キ
* 名古屋大学大学院環境学研究科 博士 (工学) (応用地質(侏)

** 名古屋大学大学院環境学研究科 教授.工博

*** 名古屋大学大学院環境学研究科 教授 $\cdot$ 理博

**** 名古屋大学大学院環境学研究科 准教授.工博
Graduate School of Env. Studies, Nagoya Univ., Dr. Eng.

(OYO Corporation)

Prof., Graduate School of Environmental Studies, Nagoya Univ., Dr. Eng.

Prof., Graduate School of Environmental Studies, Nagoya Univ., Dr. Sci.

Assoc. Prof., Graduate School of Environmental Studies, Nagoya Univ., Dr. Eng. 


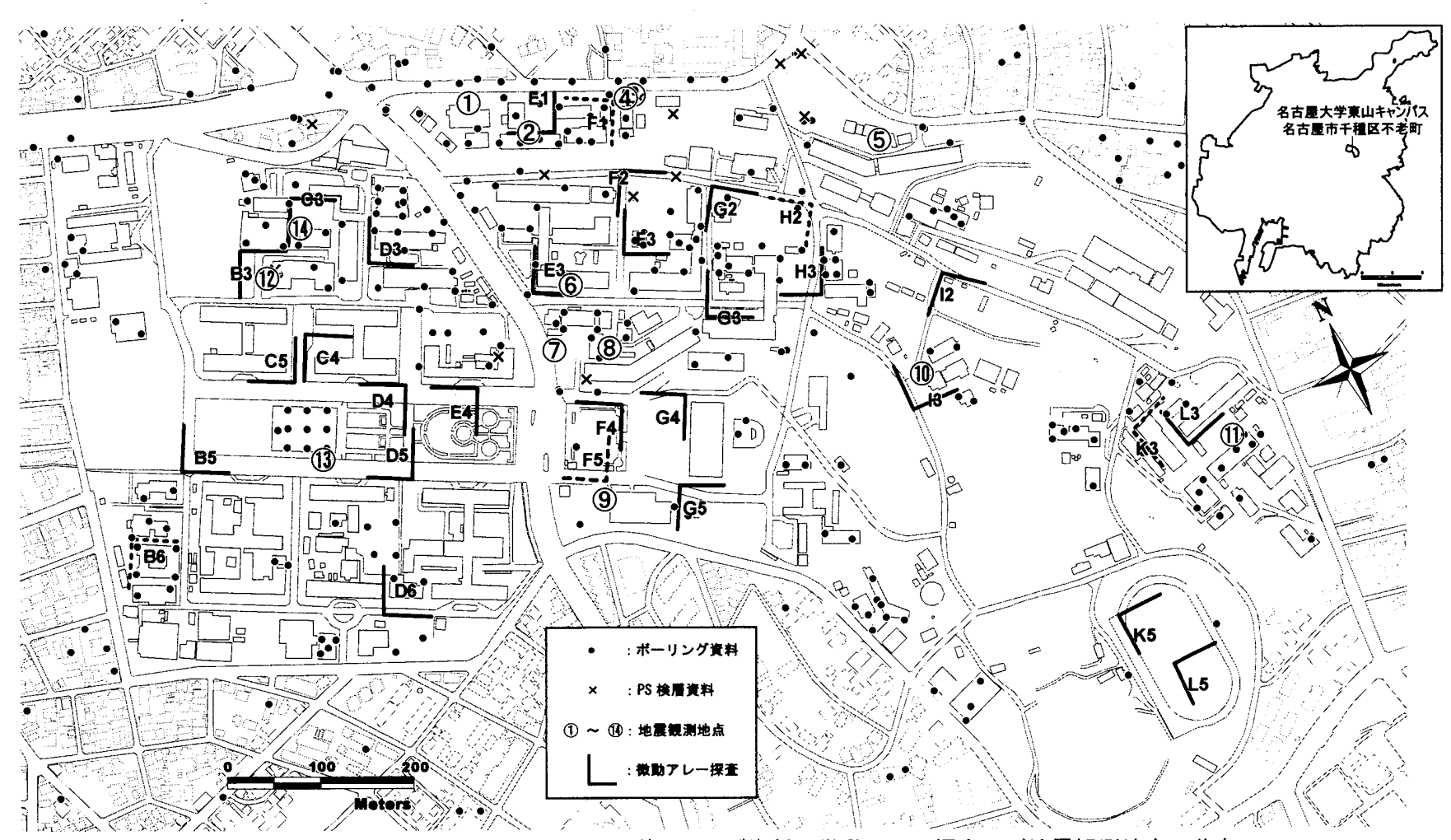

図 1 名古屋大学東山キャンパスにおけるボーリング資料, 微動アレー探査及び地震観測地点の分布

ヤンパスにおいては 14 箇所で地盤の地震観測を行っており, 強震記 録に基づく地点間の震動特性の差異についてボーリング資料と対比 して検討しているう。ままた, キャンパス内では図 1 に示す 30 箇所で 微動アレ一探査を行い, 表層の $\mathrm{S}$ 波速度構造と地質断面図と比較し てその妥当性を検討している ${ }^{6)}$ 。

本論では，造成された丘陵地の例として名古屋大学東山キャンパ スを対象とし，空中写真を活用した地形分類及び切土・盛土分布の 把握を行い，この結果と微動探査，ボーリング資料を組み合わせて 表層地盤の詳細なモデル化に関する検討を行う。さらに強震観測記 録と比較し，本モデル化の妥当性を検討する。本モデル化手法は同 様の造成された丘陵地において適用可能と考えている。表 1 に本研 究に用いた資料の一覧を示寸。

\section{表 1 本研究に用いた資料の一覧}

\begin{tabular}{|c|c|c|}
\hline 資料名 & 年代 & 得られる情報 \\
\hline 都市計画基本図（縮尺 1/3000） & 1958 年 & 標高值 \\
\hline 都市計画基本図（縮尺 $1 / 2500 ）$ & 1998 年 & 標高值 \\
\hline 地形図（縮尺 1/25000） & 1932年 & 標高値 \\
\hline 空中写真 (撮影縮尺 $1 / 10000$ 吅日本陸軍撮影) & 1930 年代 & 地形分類，標蒿值 \\
\hline 空中写真（摄影縮尺 $1 / 10000$, 米軍撮影) & 1940 年代 & 地形分類, 標高値 \\
\hline ボーリング資料（261 地点） & 1960 年代 & 地下゙の層構造 \\
\hline 微動アレイ探查（30籄所） & 現況 & 地下のS波速度構造 \\
\hline 地震観測記録（14 地点） & 現況 & 地盤震動特性 \\
\hline
\end{tabular}

\section{2. 地盤条件の推定}

\section{1 微地形分類}

表層地盤の構造や地形条件が地震被害と密接な関連を持つこと は古くから指摘されており ${ }^{71.8)}$, 液状化を引き起こす地震動強さと微 地形との関連が高いことも示されている 9.10).11)。したがってサイス ミックマイクロゾーニングにおいて，当該地域がどのような地形条 件に該当するかを詳細に把握することは，極めて重要である。地形 条件に基づいた広域地盤特性の評価として，国土数值情報を用いて
地盤特性を推定し地震危険度を求める試みがなされている ${ }^{12) .13)}$ 。し かしながら国土数值情報はメッシュサイズが $1 \mathrm{~km}$ であるため，本論 で扱うような $2 \mathrm{~km}$ 四方の領域内の細やかな地盤特性の違いを把握 するには適さない。一方，土地条件図は1950年より継続して作成さ れており，高解像度の地形分類を把握するのに適しているが，対象 地域は戦前から造成が行われており原地形が分からない。図 2 に対 象地域における土地条件図を示す。図 2 より，対象地域はほとんど の領域が人工改変地及び盛土地とされ，土地条件図から元の地形が 谷であるか段丘面であるかを判断することは難しい。

一方で, 対象地域には地形改変前の情報として，1930 年代に旧日 本陸軍が撮影した空中写真がある（撮影縮尺約 1/10000）。図 3 に, 旧日本陸軍が撮影した空中写真を示寸。図 3 より，対象地域には建 物がほとんどないことから，地形改変前の状態であることが確認で きる。微地形の推定方法として, 古い時期の土地利用や衛星データ から推定する試みがなされている ${ }^{1+1}$ が，本論では空中写真を実体視 判読して地形分類を行い，造成前の地形分類図を作成した。図 4 に 対象地域における地形分類図を示す。図4を図 2 と対比して見ると， 段丘面と谷底平野が複雑に入り組んだ地形を造成して現在に至って いることが分かる。

都市部においては本地域と同様に早い時期に地形改变が行われ ていると考えられるが，そのような地域には旧日本陸軍撮影の空中 写真もしくは 1940 年代に米軍が撮影した空中写真があり，1940 年 代以前の大規模な地形改変は少ないことから, 本論と同様の検討は 他地域でも可能と考えられる。

\section{2 切土・盛土分布の作成}

対象地域は，施設建設に伴い造成を繰り返してきた。地震被害と 造成地盤との関係については今までに多くの研究がなされている。 
その中で, GIS（Geographic Information System）を用いて, 新旧の 都市計画基本図から 3 次元の地形変化を算出することにより, 地震

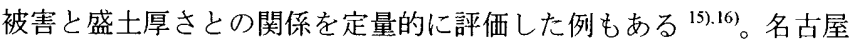
市では 1958 年から都市計画基本図（1960 年代まで縮尺 1/3000）が 整備されているが，前述のとおり，1950 年代には対象地域の造成は 既に進められており，地形改変前の標高値を得ることができない。 地形改変前の地形を把握できる図幅として，1/25000 旧版地形図が あるが, 地形図の標高精度は, 等高線は主曲線間隔の 2 分の 1 以内, 標高点は主曲線間隔の 3 分の 1 以内と規定されており, 等高線をデ ジタイズして地形の標高を求める場合, 都市計画基本図は土1.0m, $1 / 25000$ 地形図は $\pm 5.0 \mathrm{~m}$ の誤差を含む。鹿户・他は，1/25000 地形図 による切土・盛土厚さを $1 / 2500$ 都市計画基本図による切土・盛土厚 さと比較し，その様相が異なることを指摘している ${ }^{16)}$

一方で，地形改変前の情報としては，図 3 に示した旧日本陸軍に よる 1930 年代の空中写真（撮影縮尺約 1/10000）があり, これを用 いて写真測量により地形改変前の標高を推定した。古い時期の空中 写真の測量において, 鈴木・他は最新の都市計画基本図に表現され ている不動点を GCP（Ground Control Point）として用い，1940 年代 の米軍撮影の空中写真を図化し, $\pm 0.7 \mathrm{~m}$ 程度の誤差で测量可能なこ とを示している ${ }^{17)}$ 。本研究では, 旧日本陸軍撮影の空中写真に鈴木・ 他 ${ }^{17}$ と同様の方法を用いて推定した。GCPには，都市計画基本図と 写真を比較し, 経年変化していないと思われる交差点の中心を用い た。植栽の影響は，代表的な植栽の標高差を計測し，その值を踏ま えて地表面の等高線を推定した。写真測量の計測精度を，標定作業 後の GCPにおける垂直方向の残差によって検討したところ, 地表の 露出している対象地域の北部では標準偏差で水平方向 $\pm 0.74 \mathrm{~m}$, 垂 直方向 $\pm 0.89 \mathrm{~m}$, 植栽による被覆部が多い南部では水平方向 $\pm 0.69 \mathrm{~m}$, 垂直方向 $\pm 1.26 \mathrm{~m}$ であった。

上記の過程を経て得られた写真測量に基づく標高値の精度を，都 市計画基本図から得られる標高の精度と比較した。まず，写真測量 及び 1958 年の都市計画基本図（縮尺 1/3000），1998 年の都市計画基 本図（同 1/2500），1932 年の 1/25000 地形図『名古屋南部』より 10mDEM（Digital Elevation Model）をそれぞれ作成し，地形改変の 行われていない領域の標高値をピックアップした。その上で航測し ーザー測量により作成されている国土地理院の $5 \mathrm{~m}$ メッシュ標高 ${ }^{18}$ を基準として，同じ座標の標高差をそれぞれ計算し，そのばらつき を比較した。

図 5 に，国土地理院の $5 \mathrm{~m}$ メッシュ標高 ${ }^{18)}$ の地形面を基準とした 写真測量, 1998 年都市計画基本図, 1958 年都市計画基本図, $1 / 25000$ 地形図との標高差の相対度数分布を比較して示す。相対度数分布の 階級値は $0.5 \mathrm{~m}$ 刻みとした。図 5 より, 写真測量による標高値は, 1958 年都市計画基本図と同等のばらつきを示していることが分か る。データの標準偏差は \pm 1.92 であり，1958 年都市計画基本図の標 準偏差 $\pm 1.42,1998$ 年都市計画基本図の標準偏差 \pm 2.03 とほぼ同等の 值を示している。一方，地形図による標高値は，写真測量及び 1998 年都市計画基本図に比べてばらつきが大きく，各図幅から得られる 誤差とほぼ対忍している。これは鹿戸・他 ${ }^{109}$ の検討とも整合する。 以上より，国土地理院撮影の空中写真に比べ状態の悪い旧日本陸軍 撮影の空中写真を用いた写真測量による標高の精度は，都市計画基 本図と同等の精度と考えられる。
図 6 に，造成前の地形面を示す。これと現況の地形面との標高值 の差分から切土・盛土の厚さ分布を求めた。図 7 に東山キャンパス 内の切土・盛土の分布を示す。本研究では $1 \sim 20 \mathrm{~Hz}$ の地盤震動特性 を対象としている。前述の通り, 本検討における写真測量の標高精 度は土 $2 \mathrm{~m}$ 以内であるが，表 2 に示す盛土部の $\mathrm{S}$ 波速度 $157 \mathrm{~m} / \mathrm{sec}$ を 用いて 4 分の 1 波長則により検討すると, $\pm 2 \mathrm{~m}$ 以内の精度は $20 \mathrm{~Hz}$ 以上の周波数域に影響を及ぼす。以上より, 図 7 に示す切土・盛士 は本研究では適用可能と考えられる。

\section{3. 地下構造の推定}

\section{1 標準貫入試験データに基づく S 波速度構造の推定}

ボーリング資料から文献 ${ }^{2} に$ 倣って，表 2 の第 3 層以下の $\mathrm{S}$ 波速 度層境界面を次の手順で作成した。

(1)各ボーリング資料を, 式(1)に従って $\mathrm{N}$ 值の変動が大きい哚度で層 区分し、平均 $\mathrm{N}$ 值による層構造化を行った上で，図 8(a)のように 平均 $\mathrm{N}$ 値の分布を示卞断面を作成する。

$\log _{10}(\delta \bar{N}) / \log _{10}(\bar{N}) \leq 0.7$

ここで, $\bar{N}$ :平均 $\mathrm{N}$ 値, $\delta \bar{N}$ : 標準偏差である。

(2)地質年代ごとに, 各ボーリングの平均 $\mathrm{N}$ 值と層順・ボーリング資 料間の連続性を断面上で判断し，全ボーリングにお゙いて共通と見 なせる平均 $\mathrm{N}$ 値の上面深度を抽出する。

(3)抽出した層の上面深度をクリギング法 ${ }^{19}$ による線形補間により補 間し， 3 次元的な層境界を作成する。

(4)抽出した層の平均 $\mathrm{N}$ 值 $\bar{N}$ を更に平均した值 $\overline{\bar{N}}$ (以下, 代表 $\mathrm{N}$ 値) から $\mathrm{N}$ 值と $V s$ の関係 ${ }^{2)}$ より $\mathrm{S}$ 波速度を推定する。

(2), (4)の結果, 得られた層と地質年代との対応を表 2 に, 層構造 断面の一例を図 $8(b)$ に示す。

表 2 作成した層構造と各層の平均 $\mathrm{N}$ 值, $\mathrm{S}$ 波速度の一覧

\begin{tabular}{|c|c|c|c|}
\hline No & 地層件代 & 平均 $\mathrm{N}$ 值 & $\mathrm{Vs}(\mathrm{m} / \mathrm{s})$ \\
\hline 1 & 盛土 & 9.3 & 157 \\
\hline 2 & 沖積層 & 9.9 & 167 \\
\hline 3 & \multirow{3}{*}{$\begin{array}{c}\text { 八事·唐山層 } \\
\text { (洪積層) }\end{array}$} & 37.1 & 349 \\
\hline 4 & & 15.0 & 216 \\
\hline 5 & & 55.3 & 382 \\
\hline 6 & \multirow{2}{*}{$\begin{array}{l}\text { 矢田川累層 } \\
\text { (第三紀層) }\end{array}$} & 13.3 & 235 \\
\hline 7 & & 40.5 & 314 \\
\hline
\end{tabular}

\begin{tabular}{|c|c|c|c|}
\hline No & 地層年代 & 平均 $\mathrm{N}$ 値 & $\mathrm{V}_{\mathrm{s}(\mathrm{m} / \mathrm{s})}$ \\
\hline 8 & \multirow{6}{*}{$\begin{array}{l}\text { 矢田川累層 } \\
\text { (第三紀層) }\end{array}$} & 17.6 & 252 \\
\hline 9 & & 41.5 & 316 \\
\hline 10 & & 19.5 & 259 \\
\hline 11 & & 59.2 & 346 \\
\hline 12 & & 21.4 & 266 \\
\hline 13 & & 78.3 & 500 \\
\hline
\end{tabular}

\section{2 地形分類に基づく沖積層厚の推定}

図 4 に示すように，ボーリング資料の分布に疎密があり，ボーリ ング資料のみの補間では, 谷底平野部に堆積する沖積層を適切に評 価できない。本研究の対象地域は, 名古屋市の中央部を南に流下す る山崎川の上流部にあたり，丘陵を刻む谷の谷底部には細長い谷底 平野が樹枝状に発達している ${ }^{20)}$. 21)。このような河川では一般に上流 部ほど谷幅が狭く, 沖積層厚は小さい。従って, 対象地域において は谷底平野の形成過程がほぼ同様と仮定し，沖積層厚を推定した。 方法は，2.1で作成した地形分類図において谷底平野に該当するボ 一リング資料を用いて, 谷幅と沖積層厚の関係を求め, これに基づ き沖積層基底面を作成した。図 9 亿谷幅と沖積層厚の関係を示寸。 ここで, 谷幅は GIS を用い，ボーリング位置を通り谷底平野のポり ゴンを分割する最小の線分の長さを谷幅と定義している。またボー リング資料は谷の中心部のデータのみを用いた。これに基づき谷幅 と沖積層厚の関係式(2)を求めた。 


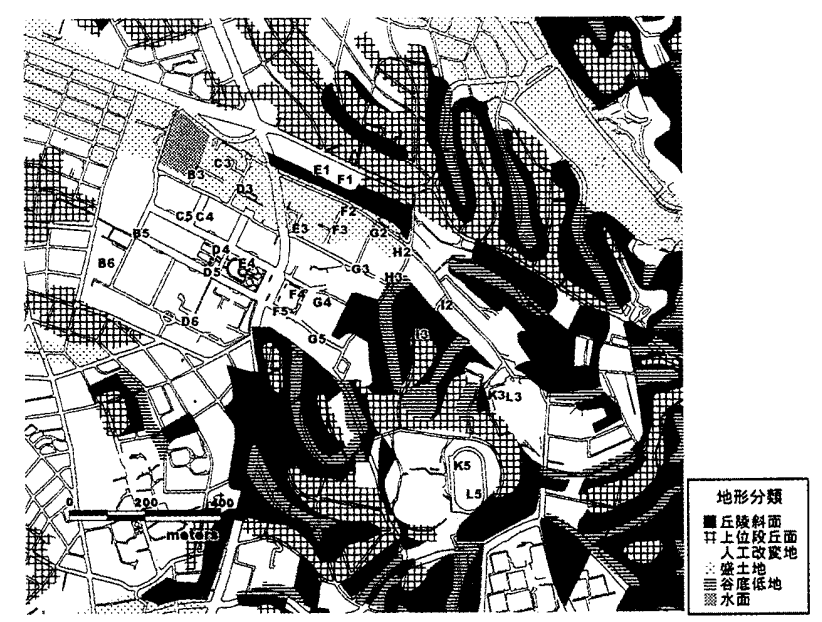

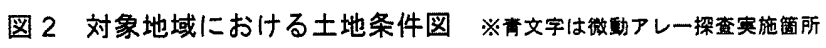

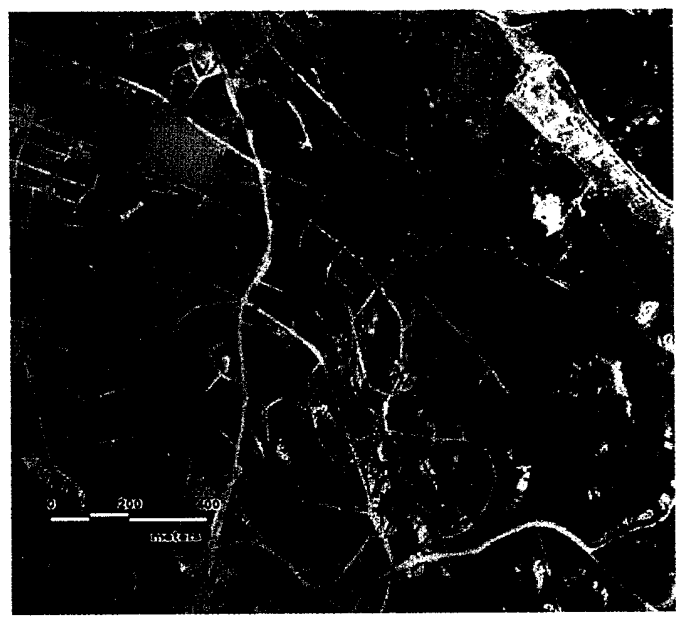

図 3 対象地域における空中写真（旧日本陸軍撮影）

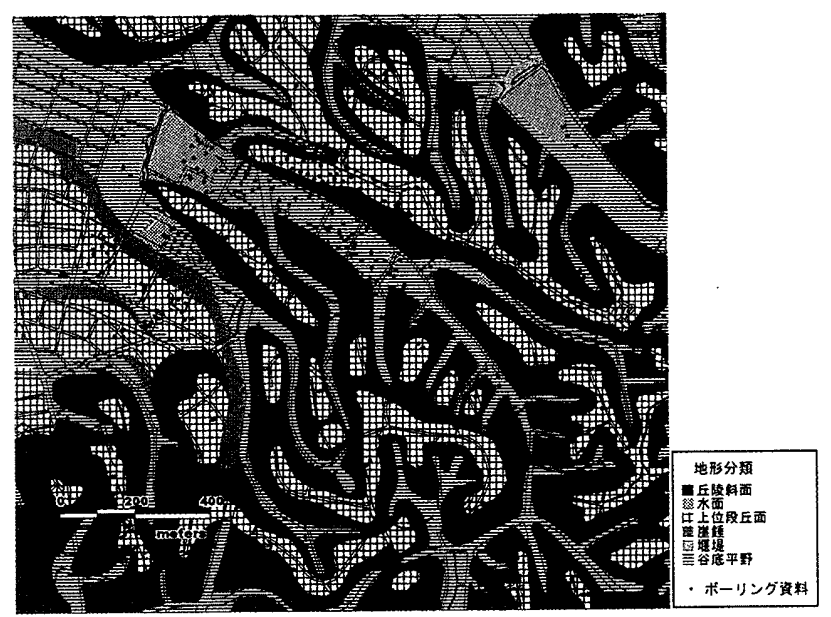

図 4 地形判読により作成した地形分類図

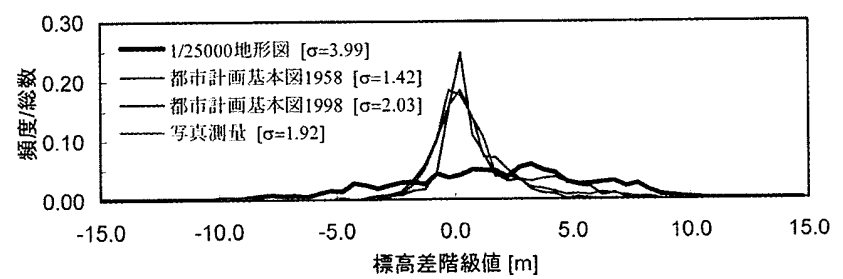

図 5 写真測量·1958 年及び 1998 年都市計画基本図·1/25000 地形図と $5 \mathrm{~m}$ メッシュDEM との標高差分の相対度数分布

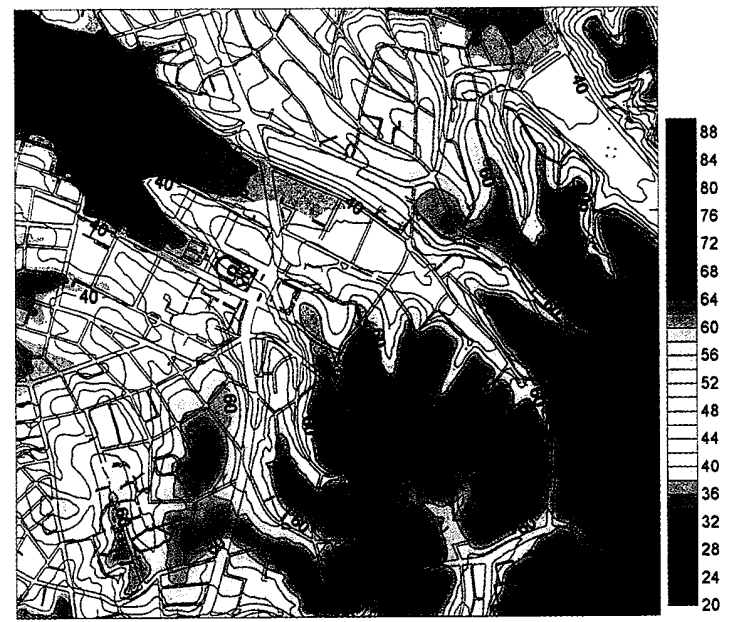

図 6 写真測曾に基づく造成前の標高 $(m)$

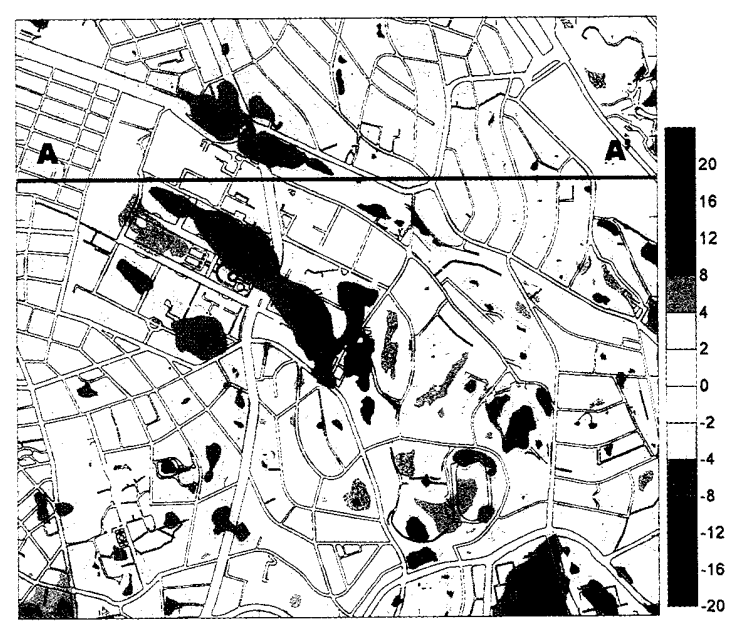

図 7 切土·盛土分布（赤：盛土，青：切土）

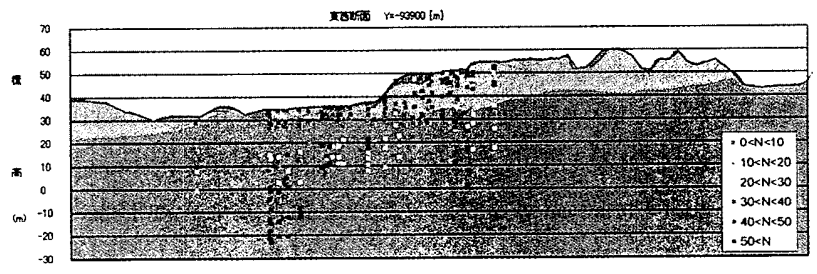

(a) $\mathrm{AA}^{\prime}$ 断面における地層年代とボーリング資料による平均 N 值の分布

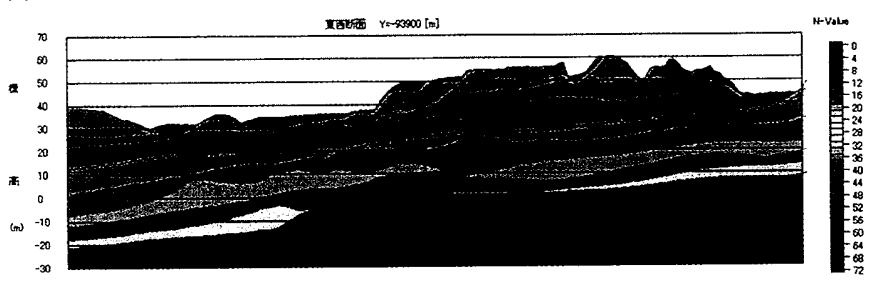

(b) 空間補間による平均 $\mathrm{N}$ 值の層断面

図 8 作成した地盤構造の断面の一例

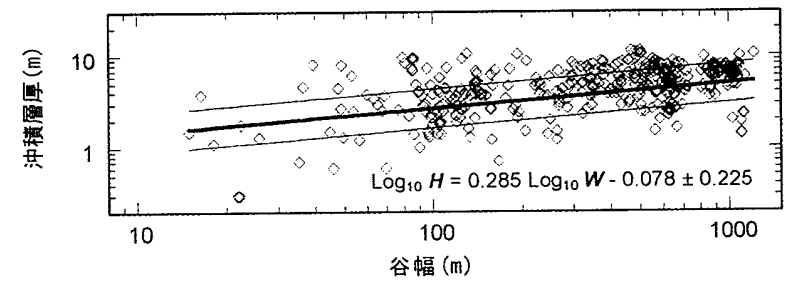

図 9 谷幅 $(m)$ と沖積層厚 $(m)$ との関係 

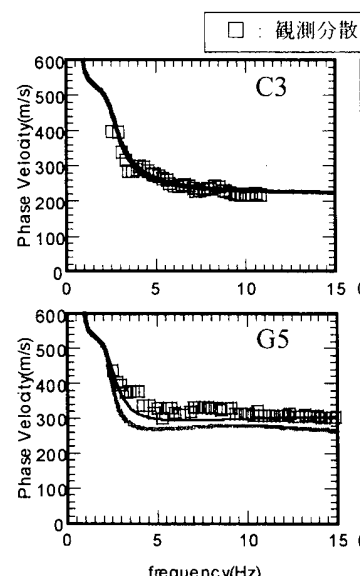
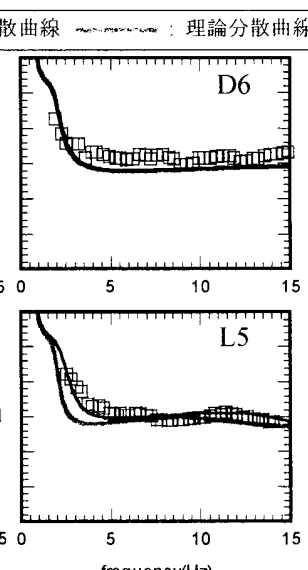

frequency $(\mathrm{Hz})$
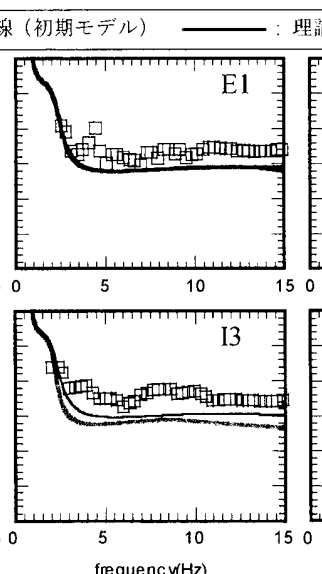

13
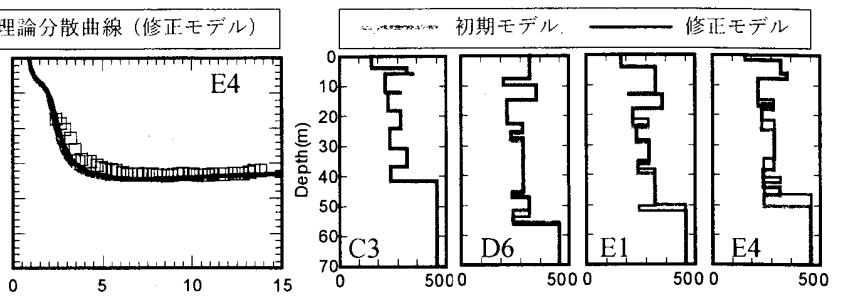

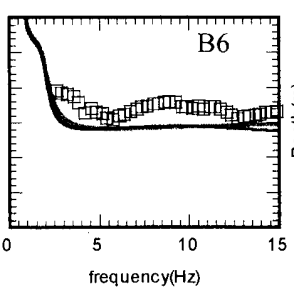

frequency $(\mathrm{Hz})$

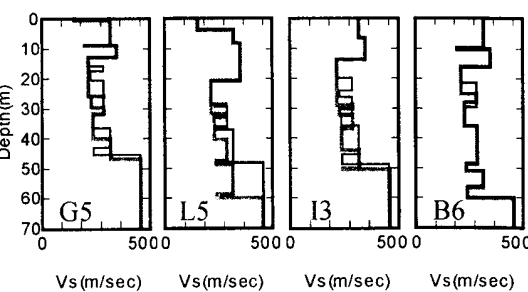

図 11 修正前後の地盤モデルの比較 $\log _{10} H=0.285 \cdot \log _{10} W-0.078 \pm 0.225$

ここで， $H$ は沖積層厚 $(\mathrm{m}), W$ は谷幅 $(\mathrm{m})$ である。式(2)を用いて，沖 積層基底面を作成した。先ず, 谷の中心をとおる点を任意に設定し、 各点における谷幅から沖積層厚を回帰式より求めた。これとボーリ ング資料に基づく沖積層厚を用いて、クリギング法 ${ }^{199}$ の線形補間に より沖積層基底面を推定した。

\section{3 微動アレー探査に基づく地下構造の修正}

図 1 に示す 30 箇所で微動アレー探査を実施し,得られた分散曲線 に基づき，前項までに作成した表層地盤モデルの修正を行った。微 動アレー探査は図 1 に示すようにL 字のアレーで行った。L字アレ 一の妥当性は文献 ${ }^{6)}$ で確認している。センサーの最小間隔 $10 \mathrm{~m}$, 最 大間隔 $70.7 \mathrm{~m}$ のアレーを展開し, 分散曲線は SPAC 法 ${ }^{22)}$ により推定 した。また, 微動アレ一探査の実施箇所は, 図 2 に示す地表面の平 坦化された地域で，アレー内に切土・盛土の境界を含まないように 選定したが，一部斜面に該当する箇所でも実施した。一方，アレー の三角形の重心位置にあたる地盤モデルを用いてレイリー波基本モ 一ドの理論分散曲線を求め, これと観測分散曲線と比較した。両者 の整合性が墨場合は，速度を固定して層厚をパラメターとして非 線形最小二乗法により修正值を求め, 改めて各層境界面を補間した。

図 10 に地盤モデルの修正前後における理論分散曲線と観測分散 曲線を比較して示す。図 1, 図 10 よりボーリング資料が密な箇所 (C3 等）では修正の必要がなく, 修正後の理論分散曲線に大きな変化が 見られない。一方，ボーリング凟料の少ない箇所 (G5，L5 等) で は，修正前の地盤モデルによる理論分散曲線は，観測分散曲線との 対応が悪いことが確認できる。また，13 は図 2 に示すように斜面に あたる箇所で実施したが，層厚の修正では観測分散曲線を満たす構 造を得ることができなかった。これは水平成層を仮定する微動アレ 一探査の限界であり，適切な観測分散曲線が得られなかったものと 考えられる。なお，B6 の観測分散曲線は，理論分散曲線より速い位 相速度が得られた。同様の傾向が見られた䇢所を図 1 に破線で L 字 を示した。これらのアレーの付近には地下階のある校舎や地下鉄が 通っているため, 非線形最小二乗法による積極的な地盤モデルの修 正を行っていない。微動アレ一探査結果に抢ける構造物の影響は, 高次モードの考慮 ${ }^{23)}$ ，建物の根人れ部分の速度の考慮などの検討が
必要であり，今後の課題である。

\section{4. 地震観測記録との比較}

作成した地盤モデル（以下，モデル A）の妥当性を検証するため， キャンパス内の 14 箇所の地震観測点にて地盤モデルと観測記録の 比較を行った。地震観測点のうち(12)地点は, $V s=530 \mathrm{~m} / \mathrm{sec} の 工$ 学的 基盤相当層（G.L.-57m）でボアホール地震観測を行っている。そこ で検証方法は，次の 2 段階の手順をとることとした。先ず, (12)地点 に゙おいて地表／孔中のスペクトル比を地盤モデルに基づく増幅特性 と比較しその妥当性を確認した。次いで, (12)地点の地表を基準とし た他地点とのスペクトル比を, 地盤モデルに基づくスペクトル比と 比較することとした。

地盤モデルに基づくスペクトル比は，震源から各サイトまでの統 計波 ${ }^{2+)}$ のスペクトル比によって評価した。比較に用いた地震は, 1997 年 3 月 16 日に愛知県東部で発生した地震（Mj5.6）である。統計波 の算出は，レイトレーシングに基づく地震基盤への入射角及び各波 動成分の増幅特性を考慮する方法 ${ }^{25)}$ を用いた。震源特性は F-net に よるパラメターを用いた。震源からサイト近傍までの伝播経路の Q 值は，中央防災会議の資料 ${ }^{26)}$ 参考に $Q=100 f^{07}$ とした。深部地盤 構造は愛知県のモデル 27)を用いた。なお，表層地盤の減衰は福島・ 翠川 ${ }^{28)}$ による土質別の周波数依存型の $\mathrm{Q}$ 值を設定した。なお放射特 性は, $0.5 \mathrm{~Hz}$ 未満は理論放射特性, $2 \mathrm{~Hz}$ 以上を等方的な特性とし, その間を線形的に変化する周波数依存型の放射特性 ${ }^{29}$ とした。

図 12 に(12)地点における地表及び孔中のフーリエスペクトルと, 地 表孔中のスペクトル比をモデル A に基づく増幅特性（2E/E+F）と 比較して示寸。なお比較のため, 回帰式による沖積層厚や切土・盛 土，微動探查結果を考慮しないモデル（以下，モデル B）を図 12 に重衫て示す。図 12 より，(12)地点はボーリング資料が密な箇所であ り，モデル $\mathrm{A}$ に基づく増幅特性は，ピーク周波数においてモデル $\mathrm{B}$ に基づく増幅特性と大きな差異は見られず，地表/孔中のスペクトル 比のピークとも概权対応している。これより(12)地点の地表を基準と することが妥当と判断した。

図 13 に，(12)地点の地表を基準とした他地点とのスペクトル比を, モデル A及びモデル B に基づく統計波のスペクトル比と比較して示 す。図 13 より，(1)地点や(8)地点ではモデル B は高周波数側で観測 スペクトル比との対灾がよくないが，モデル A は観測スペクトル比 
との対応が改善されている。また(10)及び(11)地点では，モデル B は $10 \mathrm{~Hz}$ 未満におけるスペクトル比の山・谷が明瞭ではなく観測スペク トル比との対応がよくないが，微動アレ一探査による層構造の修正 が考慮されているモデル A では改善されている。以上より，本論に おける地形分類や切土・盛土，微動探査による表層地盤モデルのチ ューニングが有効であることが分かる。
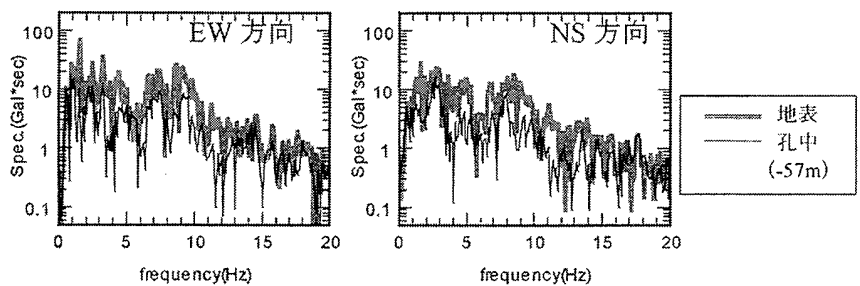

(a)フーリエスペクトル

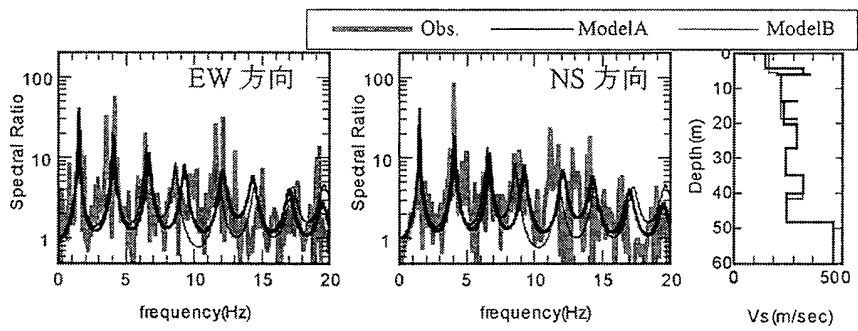

(b)スペクトル比

図 12 (12)地点における地表及び孔中のフーリエスペクトルと 地表 /孔中のスペクトル比
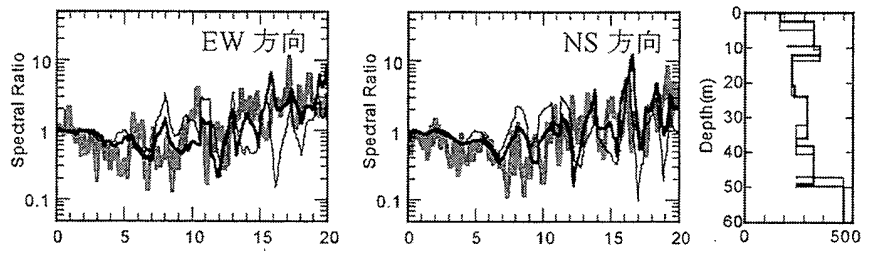

(1)地点/ (12)地点
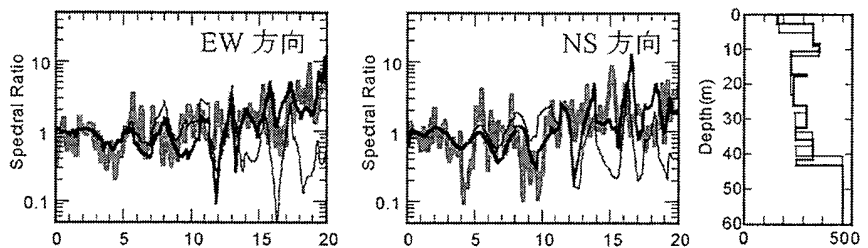

(8)地点/ (12)地点
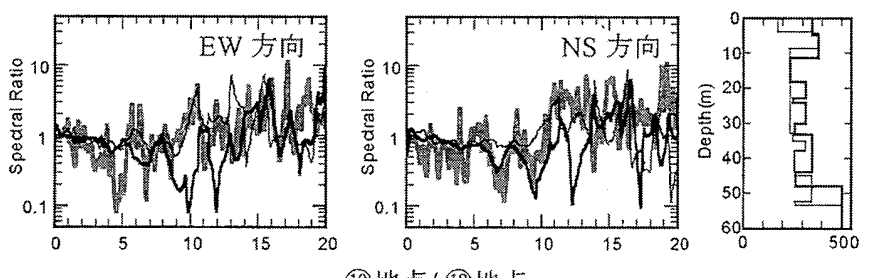

(10)地点/ (12)地点
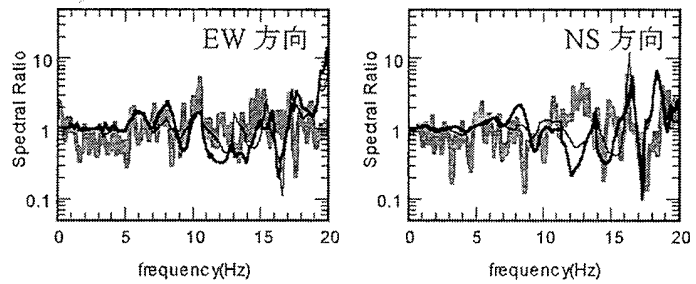

(13)地点/ (12)地点

\section{5. まとめ}

本論では, 空中写真及びボーリング資料, 微動アレー探査に基づ いて丘陵地域における地盤条件の整理を行い, これらと地震観測記 録とを比較して地盤震動特性の把握を行った。以下に得られた主た る知見を示す。

(1)旧日本陸軍撮影の空中写真を用いることにより, 既存の地形分類 図では得られない造成前の地形を判読することができた。都市部 の丘陵地域においては本地域と同様，早期から造成が行われてい ると考えられるが, 旧日本陸軍もしくは米軍が撮影した空中写真 を用いることで，同樣の検討は他地域でも可能と考える。

(2)旧日本陸軍撮影の空中写真から写真測量により地形改変前の標 高值を推定した。精度は概数都市計画基本図と同等と考えられ，

切土・盛土の評価に利用可能と考えられる。

(3)ボーリング資料に加えて, 地形分類図及び微動アレ一探査結果を 考慮した地盤モデルは，ボーリング資料のみに基づく地盤モデル と比較して，地震観測記録との対応がよいことを示した。

\section{謝辞}

本研究を進めるにあたり，地形判読には名古屋大学大学院・富田 啓介氏にご協力いただきました。写真測量には玉野総合コンサルタ ント株式会社・佐野滋樹氏にご協力いただきました。また，微動探 査の実施においては名古屋大学大学院・鈴木章弘氏をはじめとする

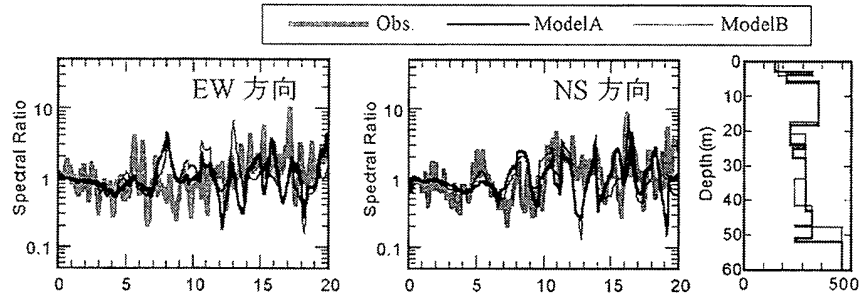

(4)地点/ (12)地点
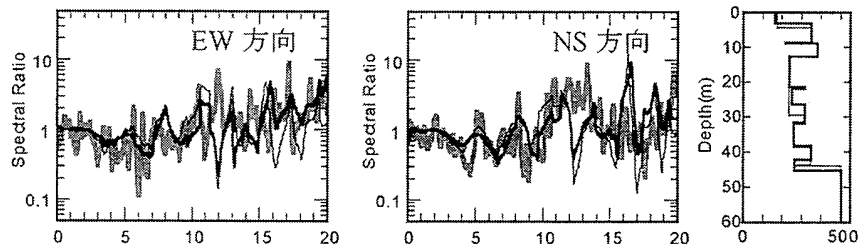

(9)地点/ (12)地点
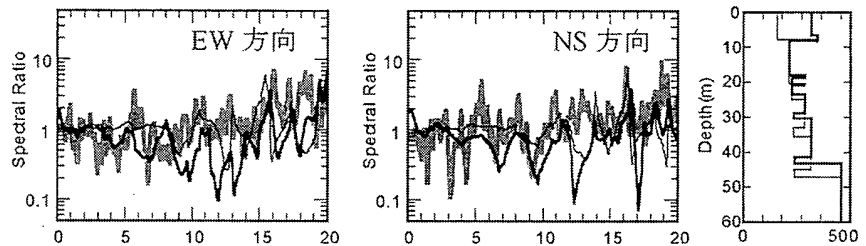

(11)地点/ (12)地点
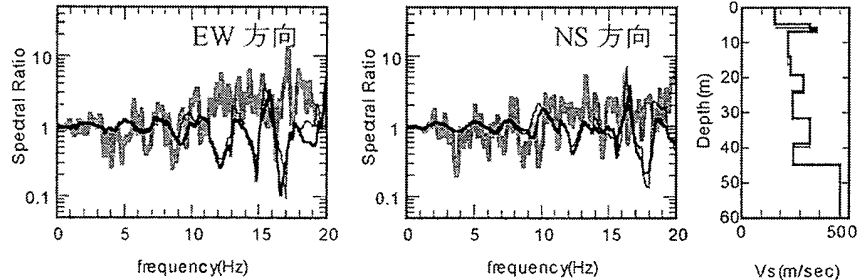

(14)地点/ (12)地点

図 13 (12)地点の地表を基準とした各地震観測地点とのスペクトル比 
学生諸氏の協力をいただきましたこここに記して,謝意を表します。

\section{参考文献}

1）内閣府（防災担当）：パンフレット「地震防災マップのすすめ」, 2005.3.

2) 高橋広人, 福和伸夫：地震動予測のための表層地盤のモデル化手法の提 案と検証, 日本建築学会構造系論文集, No.599,pp.51-59, 2006.1

3）高橋広人, 福和伸夫, 飛田潤, 古瀬勇一: 防災・安全情報を提供する施 設管理システムの構築, 日本建築学会技術報告集, 第 22 号, P.559-562, 2005.12.

4）国土地理院ホームページ : http://www.gsi.go.jp/tizu-kutyu.html

5) Tobita, J., N. Fukuwa and R. Nishizaka: Variation of Earthquake Ground Motion in Higashiyama Campus of Nagoya University, 2nd International Symposium on the Effects of Surface Geology on Seismic Motion, pp.463-468, 1998.12

6) 鈴木章弘, 木村憲司, 高橋広人, 福和伸夫, 飛田潤, 平墳義正: 地形改 変の進んだ丘陵地における浅部地盤モデルの構筑（その2）微動アレイ 探査に基づく表層地盤の $\mathrm{S}$ 波速度構造の推定, 日本建築学会大会学術講 演梗概集, pp.203-204, 2005.9

7) 望月利男, 宮野道雄, 松田磐余：1923 年関東大地震における木造家屋の 被害の検討一震央距離・地形と全壊率の関係一, 日本建築学会論文集, No. 270, pp.81-90, 1978.8

8）細野久幸，妹尾史郎，永井興史郎：地形と略算固有周期による建物基礎 地震被害の分類, 日本建築学会構造系論文集, No.605, pp. 155-161, 2006.8

9) 若松加寿江: 微地形調査による表層地盤の液状化特性の評価 1987 年千葉 県東方沖地震による液状化被害地域の検討, 日本建築学会構造系論文集, No.421, pp.29-37, 1991.3

10) Kotoda, K., K. Wakamatsu and S. Midorikawa : Seismic Microzoning on Soil Liquefaction Potential Based on Geomorphological Land Classification, 土質 工学会論文報告集, Vol.28, No.2, pp.127-143, 1988.6

11) Midorikawa, S. and K. Wakamatsu : Intensity of Earthquake Ground Motion at Liquefied Sites，土質工学会論文報告集, Vol.28, No.2, pp.73-84, 1988.6

12）松岡昌志, 翠川三郎: 国土数值情報を利用した広域震度分布予測, 日本建 築学会構造系論文集, No.447, pp.51-56, 1993.5.

13）藤本一雄, 翠川三郎：日本全国を対象とした国土数值情報に基づく地盤 の平均 $\mathrm{S}$ 波速度分布の推定，日本地震工学会論文集，第 3 巻，第 3 号, pp.13-27, 2003.

14) 中井正一, 山口祥生, 石田理永: 衛星デー夕と古い時期の土地利用に基 づく地盤特性の推定の試み一千葉市およびその周辺地域を例として-, 日 本建築学会構造系論文集, No.552, pp.69-75, 2002.2

15）小野里啓，杉村義広，菅野英幸：GIS を用いた 1993 年釧路沖地震による 宅地造成地の家屋被害の要因分析, 日本建築学会構造系論文集, No.504, pp. $57-64,1998.2$

16）鹿戸俊介, 松村紀宏, 杉村義広: 宅地造成地における家屋の地震被害率 予測に関する基礎的研究, 日本建築学会構造系論文集, No. 534, pp.65-72, 2000.8

17）鈴木康弘，佐野滋樹，野澤竜二郎：航空写真測量に基づく桑名断層の変 位地形の解析 一米軍撮影航空写真による活断層航測図化および GIS 情 報の精度一, 活断層研究, No.22, pp.76-82, 2002

18) 国土地理院: 数值地図 $5 \mathrm{~m}$ メッシュ(標高),2005

19) Hans Wackernagelm 原著：地球統計学, 森北出版, 2003.

20) 坂本亭, 高田康英, 桑原徹, 系魚川淳二: 名古屋南部地域の地質. 地域 地質研究報告（5万分の 1 地質図幅），地質調查所, $55 \mathrm{p}, 1986$.

21）新修名古屋市史編集委員会：新修 名古屋市史，第 8 巻 自然編，名古屋 市, 1996

22) Aki, K. : Space and time spectra of stationary stochastic wave, with special reference to microtremors, Bull., Earthq. Res. Inst., Vol.35, pp.415-456, 1957.

23) Tokimatsu, K., S. Tamura and H. Kojima : Effects of Multiple Modes on Rayleigh Wave Dispersion Characteristics, J. Geotech. Eng., ASCE, Vol.118,
No.10, pp.1529-1543, 1992.

24) Boore, D. M. : Stochastic simulation of high frequency ground motion based on seismological models of the radiated spectra, Bull. Seism. Soc. Am., Vol.73, No.6, pp.1865-1894, 1983 .

25) 大西良広，堀家正則：統計的グリーン関数を用いた 3 成分地震動合成法 の兵庫県南部地震への適用, 構造工学論文集, Vol.46B, pp.389-398, 2000 .

26) 中央防災会議：中央防災会議「東海地震に関する専門調査会」取りまと め資料(案), 2001

27) 愛知県：平成 14 年度濃尾平野地下構造調查成果報告書, 2003

28）福島美光，翠川三郎：周波数依存性を考慮した表層地盤の平均的な $\mathrm{Q}^{-1}$ 值とそれに基づく地盤増幅率の評価，日本建築学会構造系論文集， No.460, pp.37-46, 1994.6

29）釜江克宏, 入倉孝次郎，福知保長：地域的な震源スケーリング則を用い た大地震 (M7 級) のための設計用地震動予測, 日本建築学会構造系論文 集, No.416, pp.57-70, 1990.10.

（2006年11月10日原稿受理，2007年 4 月16日採用決定） 